\title{
Management of the patient with chronic obstructive airway disease (COPD) in a primary health care context
}

\author{
I Govender, ${ }^{1}$ HI Okonta, ${ }^{2}$ S Rangiah, ${ }^{3}$ D Nzaumvila ${ }^{2}$ \\ ${ }^{1}$ Department of Family Medicine, University of Pretoria, South Africa \\ ${ }^{2}$ Department of Family Medicine, Sefako Makgatho Health Sciences University, South Africa \\ ${ }^{3}$ Department of Family Medicine, University of KwaZulu-Natal, South Africa \\ Corresponding author, email: indiran.govender@gmail.com
}

This paper describes the incidence of chronic obstructive airway disease (COPD), the risk factors, staging, investigations and management of COPD. The differential diagnosis for COPD is also presented as COPD can be confused with other clinical conditions. This paper is presented in practical terms for the clinician working in a primary health care context.

\section{Introduction}

Chronic obstructive airway disease (COPD) is a progressive lung disease characterised by airflow obstruction that is not fully reversible and is associated with abnormal inflammatory responses of the lung to noxious particles or gases. The global prevalence of COPD is between $7-19 \%$, with variations in different regions of the world, and a predominance in men and people aged over 40 years. ${ }^{1}$ In Cape Town, South Africa, the prevalence of COPD is $22.2 \%$ for men and $16.7 \%$ for women. ${ }^{1}$ Mintz et al. have determined that $21 \%$ of patients aged 30 years or more with more than 10 years of smoking history seen in primary care settings are likely to have COPD. ${ }^{2}$ The Global Burden of Disease Study 2010 reported a prevalence estimate of $8.9 \%^{3}$ and it is expected that it will be the 6th cause of death in the world with an increase in economic and social burden. ${ }^{4}$

\section{Risk factors}

Tobacco use is the most important cause and contributing factor for COPD progression. Occupational exposures from gold mining, coal mining and cotton textile dust, indoor air pollution from burning wood and other biomass fuels, and poorly burning stoves also play a causative role. In addition, infections such as childhood respiratory infections and pulmonary TB, airway hypersensitivity, a1-antitrypsin deficiency, and demographic factors such as age, family history of atopy and low socioeconomic status, all contribute to the development of COPD.

\section{Clinical presentation}

The two subtypes of COPD - chronic bronchitis and emphysema - often coexist with their pathologic and clinical features (Table 1). ${ }^{5}$ The onset of COPD is insidious, with chronic cough, expectoration, and exertional dyspnoea. A high index of suspicion should be considered in every patient with risk factors of the disease. ${ }^{4}$

Table 1. Features distinguishing chronic bronchitis from emphysema

\begin{tabular}{|c|c|c|}
\hline Features & Chronic bronchitis (Blue bloaters) & Emphysema (Pink puffers) \\
\hline Definition & $\begin{array}{l}\text { Definition is clinical: Productive cough on most days } \\
\text { for at least } 3 \text { consecutive months in } 2 \text { successive years }\end{array}$ & $\begin{array}{l}\text { Definition is pathological: Dilatation and destruction of air spaces } \\
\text { distal to the terminal bronchiole without obvious fibrosis }\end{array}$ \\
\hline \multirow{2}{*}{ Pathology } & & $\begin{array}{l}\text { In smokers the lesions are centriacinar primarily affecting the } \\
\text { upper lung zones }\end{array}$ \\
\hline & & $\begin{array}{l}\text { In patients with a1-antitrypsin deficiency the lesions are panacinar } \\
\text { primarily affecting the lower lobes }\end{array}$ \\
\hline \multirow[t]{2}{*}{ Clinical presentation } & $\begin{array}{l}\text { Symptoms: Chronic productive cough, purulent } \\
\text { sputum }\end{array}$ & $\begin{array}{l}\text { Symptoms: Exertional dyspnoea, minimal cough, tachypnoea, } \\
\text { decreased exercise tolerance }\end{array}$ \\
\hline & $\begin{array}{l}\text { Signs: Cyanosis, peripheral oedema, crackles, wheezes, } \\
\text { prolonged expiration, obesity }\end{array}$ & $\begin{array}{l}\text { Signs: Pink skin, pursed-lip breathing, use of accessory muscles, } \\
\text { cachexia, barrel chest, hyperresonant percussion, decreased } \\
\text { breath sounds, decreased diaphragmatic excursion }\end{array}$ \\
\hline \multirow[t]{2}{*}{ Investigations } & PFT: $\downarrow F_{E V}, \downarrow F E V_{1} / F V C$, normal TLC, $\downarrow$ or normal DL $_{c o}$ & PFT: $\downarrow \mathrm{FEV}_{1}, \downarrow \mathrm{FEV}_{1} / \mathrm{FVC}, \uparrow T L C, \uparrow \mathrm{RV}, \uparrow \mathrm{DL}_{\mathrm{co}}$ \\
\hline & $\begin{array}{l}\text { CXR: Normal AP diameter, } \uparrow \text { bronchovascular markings, } \\
\text { enlarged heart with cor pulmonale }\end{array}$ & $\begin{array}{l}\text { CXR: } \uparrow \text { AP diameter, flat hemidiaphragm (on lateral x-ray, } \downarrow_{\text {cardiac }} \\
\text { silhouette, } \uparrow \text { retrosternal space, bullae, } \downarrow_{\text {peripheral markings) }}\end{array}$ \\
\hline
\end{tabular}

PFT = Pulmonary function tests; $\mathrm{FEV}_{1}=$ Forced expiratory volume in 1 second; $\mathrm{FVC}=$ Forced vital capacity; $\mathrm{TLC}=$ Total lung capacity; $\mathrm{DL}_{\text {co }}=$ Carbon monoxide diffusing capacity of lung 
During acute exacerbations, patients may present with fever, chest pain and severe shortness of breath. Physical examination may reveal respiratory distress with use of accessory muscles and intercostal recession, decreased chest expansion, barrel chest with hyper-resonant percussion, distant breath sounds and poor air entry on auscultation. There may be crackles and wheezes with prolonged expiration. The presence of cyanosis and asterixis may indicate respiratory failure secondary to hypoxemia and hypercapnia. Distended neck veins, hepatomegaly with hepatojugular reflux and bilateral pedal oedema are suggestive of cor pulmonale.

The severity of dyspnoea in COPD can be assessed using the Modified British Medical Research Council (MMRC) scale ${ }^{4}$ (Table 2).

Table 2. Modified British Medical Research Council Dyspnoea scale

\begin{tabular}{cl}
\hline Scale & \multicolumn{1}{c}{ Severity of dyspnoea } \\
\hline 1 & $\begin{array}{l}\text { Sho breathlessness except with strenuous exercise } \\
\text { walking up a slight hill }\end{array}$ \\
\hline 2 & $\begin{array}{l}\text { Walks slower than people of the same age on the level } \\
\text { because of breathlessness or has to stop for breath } \\
\text { when walking at own pace on the level }\end{array}$ \\
\hline 3 & $\begin{array}{l}\text { Stops for breath after walking about } 100 \text { metres or after } \\
\text { a few minutes on the level }\end{array}$ \\
& $\begin{array}{l}\text { Too breathless to leave the house or breathless when } \\
\text { dressing or undressing }\end{array}$ \\
\hline
\end{tabular}

\section{Investigations}

- Spirometry is used to determine the extent of airflow obstruction, assess the severity of COPD and monitor the disease progression. Spirometry is not recommended in acute exacerbation as this may be difficult to perform and may not be accurate. A post-bronchodilator $\mathrm{FEV}_{1} / \mathrm{FVC}$ of $<0.70$ is diagnostic of COPD.

- The severity of airflow obstruction is assessed using the Global Initiative for Chronic Obstructive Lung Disease (GOLD) ${ }^{4}$ criteria. (Table 3)

Table 3. COPD severity grading - GOLD criteria

\begin{tabular}{lcc}
\multicolumn{1}{c}{ Grade } & FEV $\mathbf{1}$ /FVC $^{c}$ & \multicolumn{1}{c}{ FEV $_{\mathbf{1}}$} \\
\hline $\begin{array}{l}\text { Mild COPD } \\
\text { (GOLD 1) }\end{array}$ & $<0.7$ & $\geq 80 \%$ of predicted \\
$\begin{array}{l}\text { Moderate COPD } \\
\text { (GOLD 2) }\end{array}$ & $<0.7$ & $<80 \%$ but $\geq 50 \%$ of predicted \\
$\begin{array}{l}\text { Severe COPD } \\
\text { (GOLD 3) }\end{array}$ & $<0.7$ & $<50 \%$ but $\geq 30 \%$ of predicted \\
$\begin{array}{l}\text { Very severe COPD } \\
\text { (GOLD 4) }\end{array}$ & $<0.7$ & $<30 \%$ of predicted or FEV \\
\end{tabular}

- Chest x-ray is done to exclude other conditions or identify comorbidities.

\section{Radiographic signs of hyperinflation are:}

- Increased anteroposterior diameter, increased retrosternal airspace, reduced cardiac silhouette with a vertical heart, flattening of the diaphragms, (better demonstrated on lateral chest x-ray), enlarged central pulmonary arteries and reduced peripheral vascular markings.

- Chest CT scan can demonstrate emphysema, cystic and bullous lesions.

- Echocardiogram is recommended if the physical examination findings are suggestive of cor pulmonale.

- Full blood count may show polycythaemia due to hypoxia or anaemia

- Eosinophil count > 100 cells/uL in recurrent exacerbations determines need for inhaled corticosteroid ${ }^{4}$

- Blood gases may reveal hypoxia if peripheral oxygen saturation is $<92 \%$ or respiratory failure if PCO2 $>45$

- Serum $a_{1}$-antitrypsin level is indicated in patients aged $\leq 45$ years with minimal or no smoking history, positive family history of COPD and lower lobe emphysema.

\section{Differential diagnosis}

The differential diagnosis of a patient with dyspnoea and persistent productive cough includes the following conditions:

\section{- Asthma}

Begins in childhood and is usually episodic. There may be personal or family history of allergy, eczema or rhinitis. The episodes are characterised by wheezing and the airway obstruction is reversible with bronchodilators.

\section{- Bronchiectasis}

This may be difficult to differentiate from chronic bronchitis. The sputum is copious with occasional haemoptysis. There may be past history of pneumonia, pertussis, tuberculosis and nontuberculous mycobacterium infection. Chest $\mathrm{x}$-ray finding of tram tracking (parallel narrow lines) radiating from the hilum and cystic spaces are suggestive of bronchiectasis. A high-resolution chest $\mathrm{CT}$ will show bronchial dilatation and bronchial wall thickening to confirm the diagnosis.

\section{- Pneumonia}

Usually presents with fever, chills and pleuritic chest pain. Chest percussion is dull and auscultation may reveal crackles or bronchial breath sounds. The area of infiltration is confirmed by chest x-ray.

\section{- Tuberculosis}

Usually manifests with chronic productive cough, fever, night sweats and weight loss. Chest $\mathrm{x}$-ray may reveal infiltrates, cavitation or fibrosis. A positive sputum Acid Fast Bacilli (AFB), GeneXpert or culture confirms the diagnosis.

\section{- Congestive heart failure}

Usually presents with orthopnoea and basilar crackles may be heard on auscultation. Brain natriuretic peptide level is elevated, chest $\mathrm{x}$-ray shows cardiomegaly with increased pulmonary vascular congestion, and echocardiogram confirms the diagnosis.

\section{- Lung cancer}

Patients with lung cancer may present with cough, haemoptysis, dyspnoea, chest pain, weight loss and night sweats. This needs to be considered as smoking is a risk 
factor for lung cancer and COPD. The physical examination and chest $\mathrm{x}$-ray or chest CT findings will suggest further diagnostic investigations (bronchoscopy, lung/pleural biopsy, thoracenthesis) towards tissue pathology diagnosis of lung cancer.

\section{Management}

The management of COPD is based on the GOLD grade and exacerbation history (Table 4). Tobacco use must be explored and discussed with patients at all visits and if necessary motivational interviewing to stop tobacco use must be initiated as early as possible. $^{4}$

There are management interventions that prolong survival ${ }^{5}$ (Table 5). All other management interventions provide symptom relief with no mortality benefit.
The progress of COPD is fraught with gradual decrease in FEV and episodes of acute exacerbations. Acute exacerbation of COPD is defined as sustained worsening of dyspnoea, cough, or sputum production of acute onset leading to increased use of medications. The most common trigger is viral or bacterial upper respiratory infection. Other causes include irritants from air pollution, pulmonary embolism, myocardial infarction, anaemia, and congestive heart failure.

The investigations in the setting of acute exacerbation of COPD include FBC, chest $x$-ray, ECG and pulse oximetry and/or arterial blood gas. Spirometry is not recommended in acute exacerbation as this may be difficult to perform and may not be accurate.

The management of acute exacerbation of COPD includes the following:

- The airway should be secured and ventilation assisted in patients with altered level of consciousness.

Table 4. Management of COPD based on GOLD grade and exacerbation history

\begin{tabular}{|c|c|c|c|}
\hline Patient group & Description & Non-pharmacological treatment & Pharmacological treatment \\
\hline A & $\begin{array}{l}\text { Few symptoms and low risk of exacerbation: } \\
\text { MMRC grade } 0-1 \text { or CAT score }<10 \\
0-1 \text { exacerbations per year not requiring } \\
\text { hospitalisation }\end{array}$ & $\begin{array}{l}\text { Smoking cessation } \\
\text { Physical activity } \\
\text { Vaccinations }\end{array}$ & $\begin{array}{l}\text { SAMA or SABA prn } \\
\text { SAMA + SABA prn } \\
\text { (Combination therapy is superior to } \\
\text { monotherapy })^{5}\end{array}$ \\
\hline B & $\begin{array}{l}\text { More symptoms and low risk of exacerbation: } \\
\text { MMRC grade } \geq 2 \text { or CAT } \geq 10 \\
0-1 \text { exacerbation per year not requiring } \\
\text { hospitalisation }\end{array}$ & $\begin{array}{l}\text { Smoking cessation } \\
\text { Physical activity } \\
\text { Vaccinations } \\
\text { Pulmonary rehabilitation }\end{array}$ & $\begin{array}{l}\text { LAMA or LABA } \\
\text { LAMA + LABA } \\
\text { (combination therapy is superior to } \\
\text { monotherapy) }{ }^{5-7}\end{array}$ \\
\hline$C$ & $\begin{array}{l}\text { Few symptoms but high risk of exacerbation: } \\
\text { MMRC grade } 0-1 \text { or CAT }<10 \\
\geq 2 \text { exacerbations per year, or one or more } \\
\text { requiring hospitalisation }\end{array}$ & $\begin{array}{l}\text { Smoking cessation } \\
\text { Physical activity } \\
\text { Vaccinations } \\
\text { Pulmonary rehabilitation }\end{array}$ & $\begin{array}{l}\text { LAMA } \\
\text { LAMA + LABA or } \\
\text { LABA + ICS } \\
\text { (ICS increases risk of pneumonia and } \\
\text { consequently less preferred) }\end{array}$ \\
\hline D & $\begin{array}{l}\text { More symptoms and high risk of exacerbation: } \\
\text { MMRC grade } \geq 2 \text { or CAT } \geq 10 \\
\geq 2 \text { exacerbations per year, or one or more } \\
\text { requiring hospitalisation }\end{array}$ & $\begin{array}{l}\text { Smoking cessation } \\
\text { Physical activity } \\
\text { Vaccinations } \\
\text { Pulmonary rehabilitation }\end{array}$ & $\begin{array}{l}\text { LAMA + LABA } \\
\text { LAMA + LABA + ICS } \\
\text { LAMA + LABA + ICS + Roflumilast } \\
\text { or Macrolide } \\
\text { or stop ICS }\end{array}$ \\
\hline
\end{tabular}

MMRC = Modified British Medical Research Council dyspnoea scale; SAMA = Short acting muscarinic antagonist; SABA = Short acting beta 2 agonist LAMA = Long acting antimuscarinic antagonist; LABA = Long acting beta 2 agonist; ICS= Inhaled corticosteroid

Table 5. Management interventions that prolong survival

\begin{tabular}{ll}
\hline \multicolumn{1}{c}{ Interventions } & \multicolumn{1}{c}{ Details } \\
\hline Smoking cessation & The most effective intervention for preventing progression of COPD and includes: \\
& $\begin{array}{l}\text { Behavioural therapy, nicotine replacement, varenicline (Champix), bupropion and reinforcement of cessation at } \\
\text { every contact }\end{array}$ \\
Influenza vaccination annually \\
Vaccination & $\begin{array}{l}\text { Pneumococcal vaccination at least once per lifetime but can be repeated in 5-10 years } \\
\text { Home oxygen }\end{array}$ \\
& $\begin{array}{l}\text { Prevents cor pulmonale and decreases mortality if used }>15 \text { hours/day } \\
\text { Indications include: } \\
\text { PaO }\end{array}$ \\
\hline & $\mathrm{PaO}_{2} \leq 60 \mathrm{mmHg}$ with cor pulmonale or haematocrit $>55 \%$ \\
\hline
\end{tabular}


- Oxygen is administered to maintain the $\mathrm{SaO}_{2}$ between $88-92 \%$ for $\mathrm{CO}_{2}$ retainers.

- Bronchodilators: Escalated use of SAMA + LAMA delivered by metered-dose inhaler (MDI) with spacer or nebuliser.

- Systemic corticosteroids: Oral prednisone $40 \mathrm{mg}$ daily, for 5-7 days without tapering. Alternatively, IV methylprednisolone $125 \mathrm{mg} 12$ hourly could be used but this has increased risk of side effects.

- Antibiotics: These are indicated for exacerbations with increased sputum production plus either increased dyspnoea or increased sputum purulence. The choice of antibiotics is based on patient risk factors and local antibiotic resistance patterns as follows ${ }^{5,8}$ :

1. For simple exacerbation with no risk factors $\left(\mathrm{FEV}_{1}>50 \%\right.$ predicted, $\leq 4$ exacerbations/year, no cardiac disease): 5-day course of Amoxicillin, Macrolide, Trimethoprim/ sulphamethoxazole, 2nd and 3rd generation cephalosporins.

2. For complicated exacerbation $\left(\mathrm{FEV}_{1}<50 \%\right.$ predicted, $\geq 4$ exacerbations/year, cardiac disease): 7-10 day course of Amoxicillin-clavulanate, levofloxacin or moxifloxacin.

3. For patients at risk of pseudomonas infection ( $\mathrm{FEV}_{1}<35 \%$ predicted, chronic steroid use, persistent purulent sputum): Ciprofloxacin.

\section{Prognosis}

The prognosis of COPD is variable, depending on genetic predisposition, environmental exposures, comorbidities and acute exacerbations. The single best prognostic predictor is the level of dyspnoea. The BODE index is a 10-point measure of four factors (body mass index, obstruction, dyspnoea and exercise capacity) used to predict mortality in COPD (Table 6). The probability that the patient will die from COPD increases as the BODE index score increases.

Table 6. BODE index score to predict mortality in COPD 4

\begin{tabular}{|c|c|c|c|}
\hline \multirow[t]{2}{*}{ Prognostic factor } & \multicolumn{3}{|c|}{ BODE index score } \\
\hline & +1 point & +2 points & +3 points \\
\hline $\begin{array}{l}\text { Body mass index } \\
\text { (BMI) }\end{array}$ & $\leq 21$ & & \\
\hline $\begin{array}{l}\text { Obstruction } \\
\left(\mathrm{FEV}_{1}\right)\end{array}$ & $50-64 \%$ & $36-49 \%$ & $\leq 35 \%$ \\
\hline $\begin{array}{l}\text { Dyspnoea } \\
\text { (MMRC scale) }\end{array}$ & 2 & 3 & 4 \\
\hline $\begin{array}{l}\text { Exercise capacity } \\
\text { (6-minute walk distance) }\end{array}$ & $\begin{array}{c}250-349 \\
\text { metres }\end{array}$ & $\begin{array}{c}150-249 \\
\text { metres }\end{array}$ & $\begin{array}{l}\leq 149 \\
\text { metres }\end{array}$ \\
\hline
\end{tabular}

Another prognostic tool that is sometimes used is the codex index which uses 4 factors (comorbidities, obstruction, dyspnoea and previous severe exacerbations) to predict the course of COPD.

\section{Follow-up}

Patients with COPD should be followed up regularly to monitor disease progression or development of complications. Stable COPD patients can be followed up at three to six monthly intervals while patients with severe frequent exacerbations or recently discharged from hospitalisation should be followed up at two to four weekly intervals.

At each follow up visit, determine the level of dyspnoea at rest and with exercise, the number of exacerbations and hospitalisations. The COPD assessment test (CAT) questionnaire can be used for monitoring. Smoking cessation or avoidance of air pollution should be reinforced. Assess the effectiveness of medications and side effects. If medication appears ineffective, observe inhaler technique to ensure optimal delivery of current medications before adjustments. Oxygen saturation should be determined to identify COPD patients in need of supplemental oxygen. Annual spirometry is recommended to monitor decline in pulmonary function.

\section{References}

1. Halbert RJ, Natoli JL, Gano A, Badamgarav E, Buist AS, Mannino DM. Global burden of COPD: systematic review and meta-analysis. Eur Respir J. 2006:28:523-532.

2. Mintz ML, Yawn BP, Mannio DM, et al. Prevalence of airway obstruction, assessed by lung function questionnaire. May Clin Proc. 2011 May;86(5):375-81.

3. Murray CJ, Lopez AD. Alternative projections of mortality and disability by cause 1990-2020: Global Buren of Disease study. Lancet. 1997;349:1498-504.

4. Global Initiative for Chronic Obstructive Lung Disease. Global strategy for the diagnosis, management, and prevention of chronic obstructive pulmonary disease 2019 report. Available from: https:/goldcopd.org/wp-content/ uploads/2018/11/GOLD-2019-v1.7-FINAL-14Nov2018-WMS.pdf. Accessed 4 September 2019

5. Waleed A, Fernandes S, Thang M, et al. Respirology. Toronto Notes 35th Ed. Shafarenko, Tofighi: Toronto; 2019.

6. Canavan N. Dual-action bronchodilator eases COPD exacerbations. Medscape [Serial online]. Available from: http://www.medscape.com/viewarticle/810739.

7. Rabe KF, Martinez FJ, Rodriguez-Roisin R, et al. LAMA/LABA glycopyrrolate/ formoterol fixed-dose combination, delivered using a novel MDI co-suspension delivery technology reduces risk of clinically important deteriorations in COPD versus placebo and monocomponent MDIs. AJRCCM 2017;195:A3594.

8. O'Toole D. Family Medicine Notes 7th Ed; 2019. 